\title{
Utjecaj storytelling i marketinških kampanja na djecu: bihevioralno- komunikacijski aspekti
}

Stručni rad__ DOI 10.22522/cmr20190145_ _ primljeno 6. veljače 2018.

UDK: 659.11-0.42.3:316.454.3-053.4

659.441-0 42.3:316.454.3-053.4

\section{Ivan Biošić}

Edward Bernays Visoka škola za komunikacijski menadžment (student), Zagreb, Hrvatska.

E-adresa: ivan.biosic@stud.bernays.hr

\section{Sandra Biošić}

Zagreb, Hrvatska. E-adresa: sbiosic@gmail.com

\section{Sažetak}

Djeca su nerijetko zaštitna lica marketinških kampanja poznatih brendova te se često pojavljuju u medijima. Postavlja se pitanje kako storytelling i marketinške kampanje utječu na djecu. Većinom su djeca i roditelji ciljna skupina kojoj se dobro oblikovanom pričom s integriranim edukativnim činjenicama želi približiti određena tema, rješenje problema ili navika. Djeca u globaliziranom i digitaliziranom svijetu svoje prve, svakodnevne, navike vrlo često stječu praćenjem medija, ali i u pozitivnim primjerima kampanja koje korištenjem storytellinga pokazuju znatno uspješnije rezultate za razliku od svakodnevno viđenih marketinških kampanja kojima je cilj potpora i unapređenje prodaje. Storytelling kampanje sve su češće među korporacijama zbog njihove uspješnosti, a većinom se temelje na bihevioralnom i komunikacijskom pristupu. Storytelling kampanje pokazuju osjetnu razinu većeg odaziva ključnih javnosti, djece, zbog igre s emocijama, svakodnevnim navikama, međuljudskim odnosima i razvojem djetetovog karaktera. U razvoju karaktera djeteta ponajviše sudjeluju roditelji, odgajatelji, nastavnici i stručno osoblje te djetetova okolina, ali i sami mediji od sadržaja na televiziji pa sve do igara koje u djetetovim očima sežu dalje od virtualne stvarnosti, u tzv. imaginarnu realnost. Cilj ovog rada je dobiti uvid koliki utjecaj storytelling sam, ali i u kampanjama, ima na djecu i njihove bihevioralne i komunikacijske sposobnosti. Kvalitativno istraživanje provedeno je u vrtiću na području Grada Zagreba te je obuhvatilo dvije skupine djece različitog uzrasta.

Ključne riječi: djeca, mediji, storytelling, marketinška kampanja, bihevioralne i komunikacijske sposobnosti 


\section{Storyteling i marketing}

Odnos storytellinga i marketinga nema dugu povijest. Marketinške tehnike i alati te storytelling metoda imaju zajedničke vrijednosti, ali se razlikuju po utjecaju i pristupima. Storytelling je uvriježen kao komunikacijska vještina, dok se marketing pozicionirao kao ekonomska disciplina. Philip Kotler je definirao marketing „kao društveni proces kroz koji, putem stvaranja i razmjene proizvoda i vrijednosti s drugima, pojedinci i grupe dobivaju ono što im je potrebno ili što žele“ (Kotler, 1988, str. 52). Marketing kao ekonomska disciplina ima začetke još od industrijske revolucije, dok je storytelling star koliko i čovječanstvo, ističu Recep Yilmaz i Fatih Cigerci (2018, str. 2). Marketing se, kao ekonomska disciplina, temelji na razmjeni koja zadovoljava kupca, ali i prodavača. U prodaji, a osobito u izravnoj prodaji kao sastavnici integrirane marketinške komunikacije, bitna je komunikacija, to jest način na koji je kupcu predstavljen određeni proizvod.

Steve Jobs, osnivač jedne od najpoznatijih tehnoloških tvrtki Apple Inc., bio je najbolji korporativni pripovjedač prema Carmine Gallou, starijem spisatelju i kolumnistu Forbesa (2015). Jobs smatra da pripovjedač postavlja viziju, vrijednost i program cijele generacije koja će doći, navodi Gallo u knjizi o tajnama prezentacije Steve Jobsa (2015, str. 16). Pritom, govoreći kroz metafore, prikazuje sposobnost komunikacije i riječi izgovorenih na prilagođen način samoj temi. Povijesni razvoj modernog storytellinga, kao što smo i prije naveli, seže još u same začetke čovječanstva, od stvaranja priča u antičkoj Grčkoj i crtanih prikaza u spiljama. Suvremeni storytelling, kao novija metoda, nema jedinstvenu ustanovljenu definiciju, već ga autori interpretiraju na različite načine. No, kako je jedna od ključnih uloga storytellinga kognitivno učenje, ističemo definiciju povezanu s djecom: „Storytelling je izvorni oblik učenja i ima potencijal poticanja emocionalne inteligencije i pomoći djetetu da stekne uvid u ljudsko ponašanje“ (Dujmović, 2006, str. 1). Storytelling možemo promatrati kroz prizmu marketinga, ali i kroz odnose s javnošću, retoriku te mnoge druge discipline. Trenutna pozicija storytellinga ponajviše odgovara novijem pojmu marketing odnosa s javnošću koji opisuje odnose s javnošću kao važan element promocije unutar marketinškog miksa, navodi Zoran Tomić (2016, str. 124) te nadalje pojašnjava kako se u poslovnoj praksi odnosi s javnošću i marketing smatraju jednako važnima te da najbolje rezultate daju međusobnom suradnjom. Kao najvažnije ciljeve odnosa s javnošću u domeni potpore marketingu možemo istaknuti podizanje svijesti, informiranje i edukaciju, stjecanje razumijevanja, izgradnju povjerenja i stvaranje klime koju prihvaćaju potrošači, navodi Tomić (2016, str. 125). 
Ključ kvalitetno oblikovane poruke kojoj je cilj doprijeti do ciljnih javnosti može biti u storytellingu. Mnoge poruke prenose uzbunu na svoje ciljne skupine pobuđujući određene centre te potičući emocionalni okidač koji potiče potrošača da osjeća „potrebu“ umjesto „želje“ za proizvodom, navodi Hisham Darwish (2018). Emocije su ključni dio storytellinga te su ponajviše poželjne pri upravljanju brendom. Znatno utječu na odnose prema kreiranju mišljenja o brendu. Priču koja je kreativna, jedinstvena i emocionalno pokrivena te tako posjeduje određeni potencijal za utjecanjem na ponašanje ciljnih javnosti, a pogotovo kod djece koja nemaju dovoljno razvijene kognitivne vještine. Priča posjeduje potencijal za prenošenje poruke s osobe na osobu, odnosno s roditelja na roditelja, ukoliko poruka posjeduje emotivne konotacije. Dijeljenju i viralnom širenju poruke pomoću storytellinga, društvene mreže pridonijele su time što njihov korisnik, a i ciljna javnost, može podijeliti priču jednim klikom s milijunima korisnika.

\section{Marketinške i storytelling kampanje}

\subsection{Marketinška kampanja}

Marketinška kampanja je marketinška aktivnost usmjerena ciljnim skupinama kojoj je krajnji cilj stjecanje profita ili drugih vrijednosti od važnosti za organizaciju ili osobu, a koju provodi organizacija ili tvrtka za tržišno komuniciranje, projektni kooperant (Businessdictionary.com, n.p.). Marketinške kampanje, a koje gledamo kroz vremenske i ciljne faktore, su one kratkoročnih i dugoročnih ciljeva. Kratkoročni ciljevi definirani su potrebama organizacije ili osobe te količinom marketinških aktivnosti koje je potrebno provesti tijekom produkcije. Primjer kratkoročne aktivnosti bilo bi sponzorstvo kompanije za proizvodnju dječjih prehrambenih namirnica na događaju namijenjenom za žene koje su majke. Dugoročni ciljevi usmjereni su na javnost i utjecanje na javno mnijenje. Odabir točnih ciljnih skupina, javnosti kojoj se komunicira određena poruka, od presudne je važnosti za uspješnost kampanje. Najčešće javnosti marketinških kampanja su kupci i potrošači kojima se predstavlja novi proizvod ili nudi već postojeći s određenom cjenovnom akcijom iz različitih razloga. Ciljne skupine ili javnosti moraju biti višestruko provjerene i točno određene. Jedna od tehnika evaluacije „povratne informacije“ $u$ oglašavanju definira se usporedbom stanja prije i poslije, odnosno u razlikama ostvarene dobiti. 


\subsection{Storytelling kampanja}

Storytelling kampanja komunikacijska je aktivnost usmjerena ciljnoj javnosti koja se izvodi pomoću komunikacijskih i marketinških tehnika i alata s ciljem poistovjećivanja s brendom ili određenim proizvodom ili uslugom. Cijela kampanja oblikovana je u koherentnu priču te je prožeta emocijom. Storytelling kampanja odašilje određene poruke koje su sažete u ključnoj poruci. Storytelling kampanje ponajviše teže društveno odgovornim ciljevima, ali su se počele primjenjivati i za druge ciljeve, ponajviše za prodaju. Stoga je danas potrebno uložiti analitičke napore kako bi razlikovali storytelling $\mathrm{i}$ „klasične“ marketinške kampanje. Ciljevi storytelling kampanje mogu biti razni, od stvaranja imidža, utjecaja na javno mnijenje i ponašanje javnosti, povezivanje javnosti s brendom pa sve do podizanja svijesti o važnim pitanjima te integriranja određenih stavova $u$ društvu. Svojstva storytelling kampanja su jasno odašiljanje poruke u obliku priče, istaknuto korištenje emocija naspram racionalnih činjenica, indirektan ili društveno odgovoran cilj izvođenja, uočljiva ciljna skupina, poticanje na promišljanje te poziv na akciju.

\section{Kampanje namijenjene ciljnoj skupini - djeca}

Kampanje i promotivni sadržaji koji su ciljano kreirani za dječju dobnu skupinu i zadržavanje pozornosti na određenoj materiji imaju svojstva akcije, životnosti, jake zvučne efekte te glasnu glazbu. U marketinškoj komunikaciji usmjerenoj prema djeci, zbog lakšeg privlačenja pozornosti, često se koriste audio materijali. Za razliku od takvih kampanja gdje djeca predstavljaju primarnu ciljnu skupinu kojoj se obraćamo na tržištu, postoje i kampanje koje predstavljaju proizvode ili priče koje su indirektno namijenjene djeci, ali primarno se produciraju za ciljnu skupinu roditelja. Dakle, razlikujemo kampanje kojima su djeca primarna ciljna skupina i kampanje kojima su roditelji primarna, a djeca sekundarna ciljna skupina. Za primjer možemo uzeti tvrtku koja proizvodi pelene. Budući da djeca koja nose pelene nisu niti približno kognitivno razvijena da prepoznaju potrebu za pelenama, kampanje te vrste za primarnu ciljnu skupinu imaju roditelje. Pelena je proizvod koji roditelj neće koristiti, nego ga kupuje za potrebe svog djeteta. Djeca su sposobna razumjeti kampanje oko četvrte godine života kada počinju doživljavati svijet i primjećivati objekte iz okoline. Prilikom kreiranja kampanje, marketinški odjeli tvrtki ili agencije za tržišno komuniciranje uzimaju u obzir da dijete nije samostalna osoba sa stalnim primanjima pa pritom djecu pokušavaju zainteresirati u toj mjeri da dijete pita roditelje za određeni proizvod ili uslugu. 
Kao što je navedeno u prethodnom dijelu rada, marketinškim kampanjama je krajnji cilj profit, stvaranje novih baza potrošača i unapređenje prodaje. Storytelling kampanje imaju za krajnji cilj informiranje, motivaciju i podizanje svjesnosti javnosti te su često odgojnoobrazovnog karaktera, a profit je indirektan i nastaje, na primjer, društveno odgovornim djelovanjem. Kod podudaranja storytelling i marketinških kampanja nalaze se dvije vrijednosti koje su im zajedničke: prva je da roditelji i djeca predstavljaju primarnu ciljnu skupinu, a druga ažurno praćenje trendova kod potrošača budući da se u globaliziranom svijetu navike djece često i ubrzano mijenjaju. Prema istraživanju koje donosi izvještaj YTV Kids and Tweens Report (Mediaincanada.com, 2008), kod djece se najčešće utječe na odabir doručka ( $97 \%$ vremena) i ručka (95\% vremena), gdje otići pojesti obiteljski obrok ( $98 \%$ vremena, dok u $34 \%$ slučajeva djeca biraju mjesto obroka), odabir robe i obuće ( $95 \%$ vremena), odabir i kupnju aplikacija (76 \% vremena), tehnološku kupnju (60 \% vremena), odabir obiteljskih zabavnih događaja (98 \% vremena) i obiteljskih putovanja i odmora (94 \% vremena). Svakako, djeca su ciljna skupina koja zasigurno pozornije prati kampanje te oglasni program zbog interaktivnosti, akcijskih scena, glasne glazbe i dinamičnog prikaza cjelokupnih video materijala.

\subsection{Dosadašnja istraživanja}

„Masovni mediji informiraju, odgajaju, obrazuju i zabavljaju, ali i manipuliraju, oblikuju mišljenja, nameću određene dnevne teme te su jednostavno sastavni dio života" (Labaš, Marinčić, 2018). U Hrvatskoj je od 2000. godine zabilježen porast istraživanja o oglašavanju usmjerenom na djecu te je pojačan interes stručne javnosti za navedenu temu, što potkrepljuje sve veći broj znanstvenih i stručnih skupova, konferencija i panel rasprava o odnosu djece i medija. Zaklada Kaiser Family 2006. godine provela je istraživanje među 1008 roditelja djece između dvije i sedamnaest godina u Sjedinjenim Američkim Državama (prema Labaš, Marinčić, 2018, str. 6). Istraživanje je pokazalo, kako prenose Labaš i Marinčić (2018, str. 6), da su roditelji izrazito zabrinuti za seksualne i nasilne sadržaje u televizijskim reklamama, a njihova djeca imaju slobodan pristup takvim sadržajima. Labaš i Marinčić ističu kako je jedna majka djevojčice istaknula da preuzima obrasce ponašanja s televizije: „Moja petogodišnja kći odlazi u svoju sobu i izlazi odjevena u kratku suknju i čizme. Kada ju upitam zašto je tako odjevena, odgovara mi da je to vidjela na televiziji“ (Rideout, 2007: 8 prema Labaš, Marinčić, 2018, str. 6). Labaš i Marinčić (2018, str. 9) navode i istraživanje Gfk agencije pod nazivom Youth online 2011 koje je provedeno među ispitanicima od 15 do 30 godina. „Rezultati su pokazali da najviše ispitanika vjeruje 
internetu (48\%), odnosno televiziji (29\%), dnevnim novinama (12\%), radiju (6 \%) te ostalim masovnim medijima (5 \%)“(Labaš, Marinčić, 2018, str. 9).

\section{Piagetova teorija kognitivnog razvoja i Kampanje}

Djeca u određenoj dobi čine različite kvalitativne pogreške koje u svoje ponašanje preuzimaju od djece starijeg ili mlađeg uzrasta. Kognitivni razvoj djeteta usmjeren je prema razumijevanju i kreiranju vanjskog svijeta, a bihevioralne vještine predstavljaju uključenost i upravljanje interakcijom, slušanje te društveni stil. „Dječje ponašanje je odraz strukture, ili organizacije njihova znanja ili inteligencije.“ (Vasta, Haith, Miller, 1995, str. 32) Dvije su vertikale inteligencije: organizacijska koja predstavlja znanje integrirano u kognitivne strukture i adaptivna koja omogujuće da se dijete prilagođava okolini, pojašnjavaju Vasta i suradnici (1995, str. 38). Interakcionistički pristup, to jest ponašanje i razvoj, određeni su biološko-okolinskim faktorima. Piaget predviđa četiri faze kognitivnog razvoja djeteta. Senzomotorna faza započinje rođenjem i traje do 2. godine djetetova života. $U$ toj fazi djeca upoznaju svijet i okolinu u kojoj najčešće borave, a obilježava ju fiksiranje objekata i prilagodba. Razvijaju se i motorika i osjetila, komunikacijska sposobnost je niska, djeca daju imena subjektima u okolini. Predoperacijska faza traje od 2. do 7. godine života. U njoj djeca razvijaju stavove, najčešće su egocentrična, a razmišljanje im je centrirano. Komunikacijska sposobnost raste kroz godine te se oko četvrte godine javlja sposobnost koherentnog pričanja, a već od sedme počinje strukturiranost govora. Faza konkretnih operacija započinje u 7. godini života i traje do predadolescentske dobi, to jest do 11. godine djetetova života. U toj godini započinje transdukcija, serijacija i klasifikacija. Faza formalnih operacija počinje u 12 . godini te traje do odrasle dobi. U početcima prevladava generalizacija, zatim se razvija logičko i apstraktno razmišljanje. Zaključivanje i sustavno rješavanje problema adolescent posjeduje zbog razvoja apstraktnog mišljenja. Već od sredine predoperacijske faze dijete je dovoljno razvilo svoje komunikacijske vještine, a zahvaljujući okolini u kojoj boravi, a čija su sastavnica mediji i razne marketinške kampanje koje utječu na kognitivni, ali i bihevioralni razvoj djeteta. Primjer bi bilo djetetovo gledanje crtanih filmova i sličnih audiovizualnih materijala na televiziji ili na internetskim stranicama poput YouTube kanala, a gdje se među ostalim redovito prikazuju i kampanje različitih tvrtki prilagođenih djeci. Hudson, Shapiro, McCabe i Peterson (prema Radić Tatar, 2013, str. 167) navode kako 
je pripovijedanje govorenje o zadanoj ili slobodno odabranoj temi koja se razvija zajedno s općim djetetovim razvojem. Ivona Radić Tatar (2013) pojašnjava kako je navedena tehnika vrlo složena sposobnost jer zahtijeva lingvističku, kognitivnu i socijalnu sposobnost. „Pripovijedanje ili naracija iznošenje je prošloga iskustva rečenicama koje su poredane prema vremenskomu redoslijedu (Labor, 1984). U dobi od četiri godine djeca imaju shemu za pričanje priče koja uključuje uvod, zaplet i kraj tako da su razumljiva slušateljima, a šestogodišnja su djeca sposobna pripovijedati na sasvim strukturirani način." (Radić Tatar, 2013, str. 67) Videozapisi i fotografije formati su pogodni za djecu, uzimajući u obzir da je djeci potrebno vješto prilagoditi pripovijedanje. Ako kampanja izazove emociju, što je ključni element kampanje bilo kojoj starosnoj skupini, kampanja bi se mogla ocijeniti uspješno provedenom.

\section{Kampanje s odgojno-obrazovnim ciljevima}

Kampanje koje imaju odgojne i obrazovne značajke su kampanje koje podižu svijest o određenom problemu ili temi. Za primjer se može uzeti kampanja protiv nasilja nad djecom ili kampanja koja promovira odnos majke i djeteta koju je Procter \& Gamble tvrtka provela 2017. godine (Youtube.com, 2017). Cilj takvih kampanja je osvijestiti ciljnu skupinu te ostale javnosti koje su povezane s temom ili problemom, a najčešće su okarakterizirane kao društveno odgovorne ili osjetljive. Na socijalne vještine i kompetencije djeteta tijekom njegova odrastanja, a napose $u$ dobi predoperacijske i faze konkretnih operacija, značajno utječe okolina. Dora Kralj (prema Poliklinika-djeca.hr, 2014), objašnjava kako se smatra da je dijete socijalno kompetentno ako je usvojilo prosocijalna ponašanja, kao na primjer dijeljenje, pomaganje i kooperaciju te da mu određene vještine omogućavaju razumijevanje okoline i djelotvorno snalaženje u svakodnevnim situacijama te uspješno postizanje osobnih ciljeva. Socijalna kompetencija razvija se najviše kroz socijalnu interakciju odnose s drugim ljudima i okolinom, na primjer s djelatnicima vrtića ili škole, susjedima, vršnjacima te naposljetku i novim tehnologijama te medijima. Tijekom predoperacijske i faze konkretnih operacija izrazito je bitna djetetova komunikacija s roditeljima, odnosno razgovor o viđenim socijalnim odnosima, vrijednostima i emocijama, bili oni viđeni u kampanji, crtanom filmu, seriji ili nekom drugom mediju. U marketinškim kampanjama djeci se prodaje proizvod kroz zabavu i prizmu nestašnog, ali djeci „nedozvoljenog“ ponašanja, što može dovesti do zrcaljenja i potpunog preuzimanja obrazaca ponašanja. 
Labaš i Marinčić (2018, str. 7) naglašavaju da prema Unicefovom istraživanju iz 2010. godine mediji nedostatno štite dječja prava. „Dnevne novine često su otkrivale identitet djece, ona su rijetko izvori informacija u člancima, a prilozi o djeci najčešće nisu objavljeni na naslovnoj stranici“ (Labaš, Marinčić, 2018, str. 7). Osim što mediji nedovoljno promiču prava djece i mladih, vrlo često oglašivači koriste prilike za plasman interaktivnih kampanja koje su diskutabilne i neobzirne prema ranjivoj dobnoj skupine. Oglas, prema članku 20. Zakona o medijima (NN 59/04, 84/11, 81/13), „je plaćena obavijest čiju objavu naruči pravna ili fizička osoba s namjerom da time pospješi pravni promet proizvoda, usluga, nekretnina, prava ili obveza, pridobije poslovne partnere ili u javnosti ostvari ugled ili dobro ime“. Prema istoimenom Zakonu oglas mora biti jasno naznačen i prepoznat kao takav. Postavlja se pitanje, prepoznaju li djeca kampanje kao oglasne materijale, budući da su većinom naznačeni sitnim slovima i često su na marginama samog Zakona, svojim formatom, sadržajem ili drugim karakteristikama. Prema navedenoj teoriji kognitivnog razvoja, mlađa djeca, cjelokupno gledano, teško razlikuju kampanje od ostatka programa ili sadržaja portala, novine, odnosno drugog audiovizualnog materijala. Navedenu sposobnost stječu od pete do sedme godine, kao i sposobnost shvaćanja oglasa, koju stječu tek od sedme do devete godine života (Kuterovac Jagodić, 2005, str. 4). Zakon o medijima (NN 59/04, 84/11, 81/13) definira područja koja nije dopušteno oglašavati, odnosno koja mogu biti opasna za odrasle, ali i djecu: „Nije dopušteno oglašavanje oružja i streljiva, pirotehničkih sredstava, duhana i duhanskih proizvoda, lijekova i medicinskih postupaka koji su dostupni jedino na liječnički recept, te droge, alkohola i alkoholnih pića, osim ako posebnim zakonom nije drugačije određeno." Zakon ističe i da nije dopušteno prikriveno i prijevarno oglašavanje. „Prikrivenim oglašavanjem smatrat će se svaka novinarska forma (pisani tekst, fotografija, slika, crtež i dr.) koja je na bilo koji način plaćena, a nije jasno označena kao oglašavanje.“ (Zakon o medijima, NN 59/04, 84/11, 81/13). Upravo $u$ tom segmentu oglašivači i mediji često znaju kršiti navedeno pa je tako istraživanju Jelene Jurišić i suradnika (2007, str. 128) pokazalo da je u Jutarnjem i Večernjem listu, kao vodećim tiskanim medijima u Hrvatskoj, pronađeno 327 članaka i prikaza koji sadrže jedan ili više oblika prikrivenog oglašavanja. 


\section{Metodološki okvir istraživanja}

Cilj ovog rada je utvrditi postojanje svijesti i utjecaj storytelling i marketinških kampanja na djecu te kako roditelji ili zakonski skrbnici percipiraju njihovu primjenu. Djeca su izložena raznim utjecajnim segmentima okoline, a neki od njih su navedene vrste kampanja, odnosno promidžbena industrija, a posebice danas kada su nove tehnologije integrirane u ljudsku svakodnevicu. Na temelju postavljenih ciljeva istraživanja, proizašle su sljedeće hipoteze:

$H_{1}$ : Djeca smatraju storytelling kampanje pozitivnijima od marketinških kampanja.

$\mathrm{H}_{2}$ : Društveno odgovorne storytelling kampanje potiču razvoj egocentrizma u socijalno naprednije oblike poput suradnje i njegovanja odnosa.

$\boldsymbol{H}_{3}$ : Djeca razumiju sadržaj odgojnih storytellinga i razumiju ciljeve društveno odgovornih kampanja.

$H_{4}$ : Djeca prvenstveno primjećuju kampanje na mobilnim uređajima, a zatim i na tradicionalnim medijima poput televizije, novina i radija.

Istraživanje je provedeno tehnikom fokus grupe i kvalitativne je prirode. Metodu fokus grupa Božo Skoko i Vanesa Beneković (2009, str. 217) opisuju kao kvalitativni oblik istraživanja koji uključuje grupnu raspravu o određenoj zadanoj temi. Kao osnovni cilj fokus grupe navode poticanje dubinske diskusije kojom se istražuju vrijednosti ili stavovi ispitanika prema nekoj temi, ali i kako tema ili problem utječe na osjećaje, stavove i ponašanja individua, $u$ ovom slučaju djece. Obje grupe sastojale su se od podjednakog broja djevojčica i dječaka. Istraživanju je prisustvovalo sveukupno dvadesetero djece od kojih je po desetero bilo $\mathrm{u}$ svakoj fokus grupi. Istraživanje u prvoj grupi je trajalo 30 minuta, a u drugoj 40 minuta. U istraživanju su sudjelovala djeca starije vrtićke dobi u dobi od 4 do 7 godina. Istraživanje je provedeno u dječjem vrtiću Milana Sachsa u Gradu Zagrebu. Istraživanje je provedeno u kabinetu u kojem vrtićko osoblje inače provodi radionice i edukacije s djecom. Fokus grupe su provedene $u$ jutarnjim satima. Dob djece u grupama bila je izmiješana, a djeca su sjedila u polukrugu. Audiovizualne kampanje prikazivane su na računalu na YouTube kanalu uz uporabu zvučnika. Napominjemo kako je tijekom istraživanja odgojno osoblje bilo prisutno u prostoriji. Pri vođenju fokus grupa naglasak je stavljen na komunikacijskim i bihevioralnim, odnosno kognitivnim vještinama. Djeci su prikazane četiri kampanje dvije storytelling i dvije marketinške kampanje. Osim kampanja, s djecom se raspravljalo o tehnologiji, medijima i njihovom viđenju svijeta reklama. 


\section{Rezultati i rasprava}

Rasprava u fokus grupama bila je usmjerena pomoću predloška od nekoliko grupa pitanja: određenje grupe, upoznavanje s temom, propitkivanje teme uz primjere te spoznaja. Navedeno uključuje pitanja o navikama djece, korištenju tehnologija i medija te pitanja o viđenom audiovizualnom materijalu kojeg su pogledali nekoliko puta tijekom razgovora. Nakon pripremljene prostorije, djecu je dovela pedagoška djelatnica. U uvodnom dijelu djeca su pokazala interes za sudjelovanjem. Reklame su okarakterizirali kao kratke filmove u kojima im netko pokazuje nešto, dok je jedno dijete reklo kako reklame njima govore što treba kupiti, čime je htjelo ukazati na prodajne aspekte kampanja. Također, kako i okolina ima veliki utjecaj na djecu, pokazuje informacija da je na to pitanje više djece reklo kako „reklame lažu“ i da „ništa nije tako“. Spomenuli su i industriju zabave u kojoj su reklame neizbježne te se „požalili“ kako uvijek prije gledanja filma u kinu gledaju reklame i izrazili da im to jako smeta. Djeca su priupitana mogu li se sjetiti primjera reklame, na što su se referirali na reklame trgovačkih lanaca za grickalice poput čipsa, a neki od njih su spominjali i hranu za pse, igračke i tehnologiju. Prvo što su spomenuli bile su namirnice iz sektora prehrambene industrije, a koja nerijetko djecu uzima kao ciljnu skupinu te smo takav odgovor i očekivali. Istraživanje je pokazalo da djeca u prosječnoj dobi od četvrte do šeste godine razumiju potrebe kampanja, što ukazuje na rapidan razvoj tehnologije i širenje spektra konzumenata. Jedna djevojčica je istaknula kako je gledala televiziju s mamom i vidjela hranu za pse, a koju je zatim išla kupiti u trgovački lanac jer je, kako joj je mama rekla, „mala cijena“. Sljedeće pitanje je bilo na što ih podsjećaju reklame na što su djeca odgovorila da im se jede čips kada ga vide na televiziji. Djeca su istaknula kako uvijek pitaju mamu da im kupi hranu koju vide na televiziji jer „ako oni to tamo jedu, sigurno je fino“.

Između ostaloga, djeci je prikazana kampanja tvrtke Lego, danskog proizvođača dječjih igračaka, nazvanu „Let’s Build“, u prijevodu „Idemo graditi!“ Kampanja je prikazivana na YouTubeu, na službenom kanalu tvrtke Lego, a moguće ju je pogledati na poveznici u popisu literature. U ovom hibridu storytelling i marketinške kampanje, vidljivo je kako se otac i sin zajedno igraju i da su u dobrom odnosu. Otac pomaže sinu sagraditi određene objekte od Lego kockica, dok se sin zainteresirano kreće po kući uz veselu glazbu. Djeca su mirno pogledala video te smo ih zatim priupitali što su vidjeli na videu. Odgovarali su sljedećim odgovorima: „kako grade nešto“, „zezaju se“, „zajedno se zabavljaju“, a zatim su počela njihova pitanja, a ističemo jedno od njih: „Teta, oni se igraju zajedno, a zašto je 
pas tužan “, na što im odgovaramo i objašnjavamo kako je pas inače sretan, ali on ne zna slagati kockice. Većina djece je priupitala zašto tata okreće dijete naglavačke i tako ga drži za noge te su rekli kako on to ne smije raditi i da je to ružno i loše. Navedeni odgovori jednog dječaka ukazuju na razvijene obrasce ponašanja i brigu za druge, a iz pitanja djeteta možemo vidjeti kako djeca razumiju značajke neverbalne komunikacije i mogu čitati osnovne ekspresije lica kojim izražavamo osjećaje. Djeci se posebice svidjela pozadinska glazba koju su nazvali glazbom koja „ide gore-dolje“ čime ukazuju na ton, visinu i tempo glazbe, koju smo prije istaknuli kao izrazito važan dio kampanja namijenjenih djeci. $\mathrm{Na}$ pitanje je li im zabavnije vidjeti ovakav video o Lego igračkama ili bi radije dobili brošuru, odnosno njima predstavljenu kao „papir koji opisuje izgled igračke i što s njom sve mogu raditi“. Sva djeca su odgovorila kako im je draži video jer je zabavniji i interaktivniji, a brošura je papir koji svi bacaju u smeće i nitko nikada ne čita jer je najčešće dosadan. Pitali smo ih gdje češće vide reklame, na televiziji ili internetu, na što su odgovorili kako uvijek dok su na internetu iskaču razni „videozapisi i fotografije“, ali su rekli i kako na televiziji ne mogu mirno pogledati film bez dosadnih reklama.

Prikazana im je i kampanja Prorocter \& Gamble tvrtke naziva „Thank you Mom“. Djeca su pokazala oduševljenje te rekla kako se u videu vidi da mama voli svoje dijete bez obzira na sve, te komentirali: „ovaj video pokazuje ljubav“, „u videu vidim da mama pomaže kćeri“, „mama je puno pomogla djevojčici“, ali djeca su komentirala i „ja volim svoju mamu“, ,a gdje je tata“, „ona je velika i dobra zbog mame“. Pitali smo ih i što treba reći mami kad im nešto kupi ili ih digne kad padnu ili kad se igra s njima. Na to odgovaraju svi da joj treba reći „hvala“ $i$ „mama hvala“, čime opet pokazuju socijalnu osviještenost i pravilne obrasce ponašanja koje potiče i sam video. Pitali smo ih koja je pouka oba videa na što su rekli kako je uvijek važno voljeti roditelje, odgovarali su i riječima poput „ljubav“, „obitelj“, „igra“, a naposljetku je i jedan dječak rekao kako „videozapisi“ pokazuju „sretne osjećaje“ i da „roditelje treba puno voljeti“. Na pitanje pokušava li im netko nešto prodati i djeluju li im ti videozapisi kao reklame, djeca su odgovorila da im nitko ne pokušava ništa prodati, da im video nije dosadan i da bi ga rado opet gledali.

I sudionici druge fokus grupe dali su vrlo slične odgovore na pitanje znaju li što su reklame. Opisali su ih kao kratke crtiće ili filmove koji su dosadni i vide ih svaki dan na televiziji i internetu. Također, spominju kako je to nešto nakon čega žele kupiti igračku ili nešto jesti. Jedan dječak je rekao da preskače reklame jer nisu zabavne, a druga djevojčica da ju je tata naučio prebacivanju reklama. Prilikom daljnjeg razgovora o kampanjama rekli su da su im 
najdosadnije Dormeo reklame koje traju, kako oni kažu, „cijelu vječnost“.Isto tako, spomenuli su i „ono nešto sa strujom“ i pitanjima smo došli do zaključka kako se radi o sponzoru Europskog rukometnog prvenstva - Hrvatskoj elektroprivredi. Zatim je djeci prikazan i drugi video materijal kampanje. Prikazali smo McDonaldsovu kampanju za proizvod Happy Meal (Youtube.com, 2016), prehrambeni proizvod namijenjen primarno djeci, a koju predstavljaju kao „zdravlju opciju“ prehrane u tom lancu brze prehrane. Kampanja je veselog tona, a unutar nje se može vidjeti kako animirani likovi grade veliku kutiju pakiranja Happy Meala. Nakon odgledanog videa, uočena je razlika u ponašanju nekoliko djece obrazlažući to komentarima poput: „a ja sam sad gladna“, ,ja bi opet u McDonalds“ i sličnim. Djeca su se prisjećala odlazaka u McDonalds i rekli da tamo vole provoditi vrijeme s „obitelji“, što je i prikazano u videu - animirani ljudi zajedno grade kutiju i druže se na velikom travnjaku. Djeca su naglasila i da im roditelji katkad ne dozvoljavaju odlazak u McDonalds jer je riječ o nezdravoj prehrani. Djeci se svidjela glazba i animacija videa, ali su primijetili razliku i uvidjeli da bi to sad mogli konzumirati, bihevioralno su se prilagodili onom što kampanja traži od njih. Pritom smo im prikazali istu storytelling kampanju kao i prvoj grupi, kampanju Procter \& Gamble tvrtke. Budući da video traje dvije minute, djeca su se zaista uživjela i pokazala kognitivnu sposobnost empatije i suosjećanja. Prilikom svakog pada u videu djevojke koja odrasta, djeca su izvodila facijalne ekspresije lica koje su pokazale njihove osjećaje. Nekad su dodali i komentare poput „Ajoooj“. Nakon odgledanog videa djeca su istaknula kako i njima njihove mame tako pomažu u svemu. Na pitanje što kažu kada im netko pomogne, a pogotovo mama, odgovorili su svi u isti glas „hvala“. Komentirali su kako $\mathrm{u}$ videozapisu vide ljubav, brigu o sebi i brigu za druge te da u videu vide sebe i mamu. Sve su to simboli društva i zajedništva, a i svojstva društveno osjetljivih kampanja. Iz navedenog i tijekom razgovora sa sudionicima fokus grupe ustanovili smo kako društveno odgovorne storytelling kampanje potiču razvoj centracije i egocentrizma u socijalno naprednije oblike poput suradnje i dobrih odnosa, dok marketinške kampanje djeluju na djecu tako da uzrokuju potrebu za određenim proizvodima, primjerice prehrambenim.

Obje grupe smo pitali koriste li više YouTube i internet ili televiziju. Desetero djece reklo je kako redovito koriste prijenosno računalo i tablet (internet i YouTube) i mobilni telefon jednog od roditelja (internet i YouTube) te redovito gledaju televiziju, dok šestero djece koristi samo mobilne uređaje i prijenosna računala, a tek četvero djece redovito vrijeme provodi isključivo pred televizijom. Radio ne slušaju redovito, osim „u vožnji automobilom s roditeljima“, a novine ne čitaju gotovo nikad. Niti jedno dijete nije istaknulo da roditelj s njima čita dječje knjige, slikovnice ili drugi papirnati sadržaj, uključujući tiskane medije. 


\section{Zalključalk}

U okolini je uočljiv rapidan porast plasiranja kampanja kanalima raznih medija i novih tehnologija, a u tom svijetu žive i odrasli i djeca. Marketinška, kao i prehrambena te zabavna industrija, djecu je identificirala kao istaknutu ciljnu skupinu za bolju prodaju proizvoda i prilagodila kampanje zakonskim regulativama. Nove tehnologije otvorile su mogućnost za oglašavanje usmjereno na djecu te roditelje. Kampanje koje čine većinu promidžbene industrije plasiraju se ponajviše na televiziju i internetske platforme poput popularne mreže YouTube, a najčešće se radi o novim modelima igračaka ili proizvodima prehrambene industrije. Marketinške kampanje potenacijalno su opasne zbog širokog utjecaja na djetetovu okolinu te djetetov razvoj kognitivnih vještina.

U najvećoj su opasnosti djeca mlađa od 8 godina i to zbog nerazvijenih kognitivnih vještina koje im omogućuju „obranu“ od uvjerljivih sadržaja marketinških kampanja. Upravo s time je povezana i prva hipoteza rada da djeca percipiraju storytelling kampanje pozitivnijima u odnosu na marketinške kampanje. Prva hipoteza je potvrđena s obzirom da djeca ne doživljavaju storytelling kampanje kao reklame, kako zbog interaktivnosti i cjelovite priče, tako i zbog nedovoljno razvijenih kognitivnih sposobnosti, a reklame i marketinške kampanje nazivaju „dosadnim filmovima“ i nametanjem prodaje proizvoda.

Potvrđena je i druga hipoteza istraživanja koja pretpostavlja kako društveno odgovorne storytelling kampanje potiču razvoj egocentrizma djece u socijalno naprednije oblike poput suradnje i njegovanja odnosa. Da djeca razumiju sadržaj odgojnih storytelling i primjećuju značajke društveno odgovornih kampanja pokazali su njihovi komentari na prikazane kampanje čime je potvrđena i treća hipoteza. Većina djece redovito provodi vrijeme na novim tehnologijama i mobilnim uređajima, nešto manji broj djece uz navedeno redovito prati i televiziju, dok samo dvoje djece prati isključivo televiziju s malim pristupom novim tehnologijama. Djeca sama ne odabiru radio niti imaju dodira s tiskanim medijima, čime je potvrđena i četvrta hipotezu istraživanja.

Djeca reagiraju na veseli zvuk, animaciju i snažnu interakciju. Bez obzira bila kampanja marketinška ili storytelling, na svojevrstan dobar ili loš način utječe na bihevioralno ponašanje djece koja svojim postupcima utječu na roditelje, a zajedno su ciljna skupina određenih industrija, ponajviše prehrambene i zabavne. 


\section{Popis literature}

- Dujmović, M. (2006). Storytelling as a method of EFL teaching. Metodički obzori, 1 (1), 75-87.

- Jurišić, J., Kanižaj, I., Jokoš, I., Janeš, S., Jurić, J. (2007). Manipulacija čitateljima - prikriveno oglašavanje u hrvatskim novinama. Politička misao, 44 (1), 117-135.

- Kotler, P. (1988). Upravljanje marketingom: analiza, planiranje i kontrola. Informator: Zagreb.

- Kuterovac Jagodić, G. (2005). Utjecaj televizijskog oglašavanja na djecu. Marketing UP, 12-16. Dostupno na: https://www. researchgate.net/publication/278676267_Utjecaj_televizijskog_oglasavanja_na_djecu. Preuzeto 12. ožujka 2019.

- Labaš, D., Marinčić, P. (2018). Mediji kao sredstvo zabave u očima djece. MediAnali, 12 (15), 1-32.

- Radić Tatar, I. (2013). Ovladanost vrstama rečenica na kraju predškolske dobi. Lahor: časopis za hrvatski kao materinski, drugi i strani jezik, 2 (16), 165-188.

- Skoko, B., Benković, V. (2009). Znanstvena metoda fokus grupa - mogućnosti i načini primjene. Politička misao: časopis za politologiju, 46 (3), 217-236.

- Tomić, Z. (2016). Odnosi s javnošću - teorija i praksa. Synopsis: Zagreb - Sarajevo.

- Vasta, R., Haith, M. H., Miller, S. A. (1995). Dječja psihologija. Jastrebarsko: Naklada Slap.

- Yilmaz, R., Cigerci, F. (2018). A Brief History of Storytelling: From Primitive Dance to Digital Narration. U: Y1lmaz, R., Erdem, M. N., Resuloğlu, F. (ur.), Handbook of Research on Transmedia Storytelling and Narrative Strategies. IGI-Global.

- Zakon o medijima (NN 59/04, 84/11, 81/13)

\section{Internetski izvori}

- Darwish, H. (2013). Emotional Marketing. Dostupno na: https://thinkmarketingmagazine.com/emotional-marketing/. Preuzeto 11. ožujka 2019.

- Gallo, C. (2015). Steve Jobs the Worlds Greatest Business Storyteller. Dostupno na: https://www.forbes.com/sites/ carminegallo/2015/10/08/steve-jobs-the-worlds-greatest-business-storyteller/\#7f5341d313f0. Preuzeto 8. ožujka 2019.

- Kralj, D. (2014). Socijalna kompetencija djeteta: Zašto je važna i kako ju razvijati. Dostupno na: http://www.poliklinika-djeca. hr/aktualno/teme/socijalna-kompetencija-zasto-je-vazna-i-kako-se-razvija/. Preuzeto 23. siječnja 2018.

- Lego (2014). Dostupno na: https://www.youtube.com/watch?v=rwQqkX3qZak. Preuzeto 1. veljače 2018.

- Mc’Donalds. (2016). Dostupno na: https://www.youtube.com/watch?v=6mWZUKbAhi8. Preuzeto 1. veljače 2018.

- Procter \& Gamble (2017). Dostupno na: https://www.youtube.com/watch?v=1SwFso7NeuA. Preuzeto 1. veljače 2018. 




\section{Ivan Biošić}

Ivan Biošić prvostupnik je odnosa $\mathrm{s}$ javnošću te student diplomskog studija na Edward Bernays University Collegeu. Na Bernaysu je i demonstrator na Katedri za odnose s javnošću. Voditelj je Ureda za odnosa s javnošću Vijeća studenata veleučilišta i visokih škola Republike Hrvatske i Studentskog zbora Edward Bernays Visoke škole te voditelj odnosa s javnošću Hrvatske akademske zajednice, gdje je ujedno i dopredsjednik Hrvatske akademske zajednice Zagreb. Istovremeno, obnaša i dužnost voditelja Studentske sekcije Hrvatske udruge za odnose $\mathrm{s}$ javnošću. Autor je nekoliko znanstvenih, stručnih i novinskih radova iz područja kriznog komuniciranja, neprofitne komunikacije, medija i djece, brendiranja, obrazovanja, komunikacije $u$ medicini $i$ karijernog menadžmenta. Za svoje djelovanje do sada je dobio Nagradu dekana za znanstveno-istraživački rad i studentski angažman, Nagradu za najbolju studentsku prezentaciju međunarodne znanstveno-stručne konferencije PR DAYS Mostariensis te Pohvalu dekana Bernaysa. Sudjelovao je u organizaciji više od 40 događaja povezanih s komunikacijama, marketingom, digitalnim svijetom i obrazovanjem te sudjelovao $\mathrm{u}$ recenziji sažetaka na međunarodnoj konferenciji iz područja komunikacija. Član je Hrvatske udruge za odnose $\mathrm{s}$ javnošću, Hrvatske akademske zajednice, EUPRERA-e i PRCA-e. Stručna i polja interesa su mu strateško i krizno komuniciranje, visoko obrazovanje, strateški menadžment, brendiranje i digitalne strategije. 


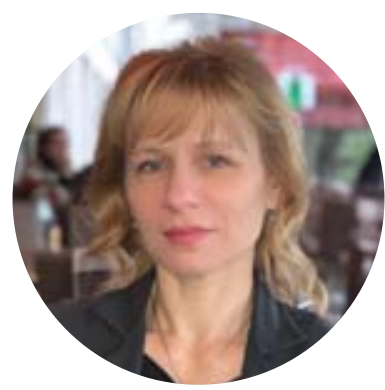

\section{Sandra Biošić}

Sandra Biošić rođena je 1972. godine u Zagrebu. Nakon završetka osnovne i srednje jezične škole, nastavlja obrazovanje na Filzofskom fakultetu Sveučilišta gdje je i diplomirala na jednopredmetnom smjeru Pedagogije. Tijekom fakulteta pohađala je razne edukacije i odradila stručnu praksu u školama i vrtiću, a jedna od edukacija bila je iz područja Waldorfske pedagogije. Iako se tijekom studija ponajviše orijentirala na pedagogiju i mlađe uzraste, usavršavala se i na edukaciji i radionicama iz područja gerontologije. Nakon fakulteta se bavila izravnom prodajom i promocijom za razne tvrtke te radila na Hrvatskoj radioteleviziji. Interesna područja istraživačkog rada su joj obiteljski odnosi, odgoj u obrazovanju te djeca u marketingu i medijima. 